\section{The lifecycle of heuristics as managerial proverbs}

\author{
Radu Atanasiu \\ Vrije Universiteit Amsterdam, Amsterdam, The Netherlands
}

Lifecycle of heuristics as managerial proverbs

\begin{abstract}
Purpose - This paper proposes a theory-based process model for the generation, articulation, sharing and application of managerial heuristics, from their origin as unspoken insight, to proverbialization, to formal or informal sharing, and to their adoption as optional guidelines or policy.

Design/methodology/approach - A conceptual paper is built using systematic and non-systematic review of literature. This paper employs a three-step approach to propose a process model for the emergence of managerial heuristics. Step one uses a systematic review of empirical studies on heuristics in order to map extant research on four key criteria and to obtain, by flicking through this sample in a moving-pictures style, the static stages of the process; step two adapts a knowledge management framework to yield the dynamic aspect; step three assembles these findings into a graphical process model and uses insights from literature to enrich its description and to synthesize four propositions.

Findings - The paper provides insights into how heuristics originate from experienced managers confronted with negative situations and are firstly expressed as an inequality with a threshold. Further articulation is done by proverbialization, refining and adapting. Sharing is done either in an informal way, through socialization, or in a formal way, through regular meetings. Soft adoption as guidelines is based on expert authority, while hard adoption as policy is based on hierarchical authority or on collective authority.

Research limitations/implications - The findings are theory-based, and the model must be empirically refined.

Practical implications - Practical advice for managers on how to develop and share their portfolio of heuristics makes this paper valuable for practitioners.

Originality/value - This study addresses the less-researched aspect of heuristics creation, transforms static insights from literature into a dynamic process model, and, in a blended-theory approach, considers insights from a distant, but relevant literature - paremiology (the science of proverbs).
\end{abstract}

Keywords Heuristics, Proverbs, Simple rules

Paper type Research paper

\section{Introduction}

Managers and firms distill their experience into managerial heuristics (Bingham and Haleblian, 2012), which are then employed purposefully as effective decision-making tools (Gigerenzer, 2008; Wübben and Wangenheim, 2008), for guiding strategy (Bingham et al., 2007; Bingham and Eisenhardt, 2011), for harnessing innovation (Manimala, 1992) or for managing customers (Bauer et al., 2013; Guercini et al., 2015). Recognizing the central role of heuristics in management, research on this topic has intensified in recent years (Loock and Hinnen, 2015) and has been synthesized in a series of literature reviews (Artinger et al., 2015; Basel and Brühl, 2013; Guercini et al., 2014; Hafenbrädl et al., 2016; Loock and Hinnen, 2015). However, most of the empirical research on managerial heuristics has employed a static perspective, studying their usage (e.g. Eriksson and Kadefors, 2017) or outcome (e.g. DeMiguel et al., 2009) at a certain moment in their evolution. Despite various calls for research on how heuristics are born and evolve (Maitland and Sammartino, 2015; Ott et al., 2017), very few studies (Bingham and Eisenhardt, 2011; Bingham and Haleblian, 2012;

(C) Radu Atanasiu. Published by Emerald Publishing Limited. This article is published under the Creative Commons Attribution (CC BY 4.0) licence. Anyone may reproduce, distribute, translate and create derivative works of this article (for both commercial and non-commercial purposes), subject to full attribution to the original publication and authors. The full terms of this licence may be seen at http:// creativecommons.org/licences/by/4.0/legalcode
Received 5 August 2019 Revised 23 April 2020 31 July 2020

11 December 2020 Accepted 8 April 2021

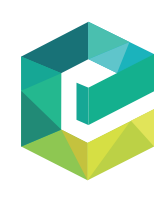

Management Decision Vol. 59 No. 7,2021 pp. 1617-1641 Emerald Publishing Limited DOI 10.1108/MD-08-2019-1025 
Guercini et al., 2015; Kazakova, 2015) have investigated how managers and firms generate their portfolios of heuristics, and often did this as a secondary research focus.

This paper answers those calls and is guided by the research question "How do managerial heuristics emerge?". Its goal is to propose a theory-based process model, from their origin as unspoken insight, to proverb-like articulation, to formal or informal sharing, and to their organizational adoption for optional use or as policy. As a first step toward drawing this model, this paper uses a systematic review of extant empirical studies on heuristics to infer the static stages of the process. By observing that heuristics are described in various stages and by assembling them in a coherent way, a dynamic perspective emerges, that of a heuristic evolving through four stages: unarticulated, articulated, shared and institutionalized. As a second step, this paper identifies in the neighboring literature of knowledge management a dynamic framework (Mertins et al., 2003) that can explain how a heuristic moves through the four stages observed before and adapts it to outline a process model for the heuristic lifecycle: generation, articulation, sharing and application. In the third, descriptive step, this paper relies on insights from empirical and theoretical papers to detail and illustrate the process and to offer four propositions on how managers generate, articulate, share, and apply their heuristics. This study follows the methodological guidelines of Cropanzano (2009), Gilson and Goldberg (2015) and Jaakkola (2020) to use a literature review approach as a tool in a conceptual paper that proposes a model and propositions.

This paper mainly contributes to the literature on managerial heuristics and decisionmaking by proposing a theory-based process model for the lifecycle of heuristics. The second contribution is to bring together the previously disparate literatures on heuristics, proverbs, knowledge management, organizational learning and sensemaking for drawing a richer understanding of heuristics as managerial proverbs that store knowledge gained through experience.

\section{Theoretical background}

\subsection{Defining managerial heuristics}

When he discovered a method to determine the purity of gold, Archimedes cried Eureka! - I found it! or I solved it!. The word heuristic has the same Greek root, and it literally means "helping to solve." Despite the increasing number of papers dedicated to this topic in the last few years (Loock and Hinnen, 2015), there is no agreed-upon definition of heuristics in a managerial decision-making context, aside from the simplifying expressions cognitive shortcuts or rules-of-thumb, leading some authors to declare that "the word heuristic has lost its meaning" (Shah and Oppenheimer, 2008, p. 207) and "may not express a single, unified concept" (Chow, 2015, p. 978). This paper follows the method employed by Dane and Pratt (2007) and by Maitlis and Christianson (2014) to aggregate disparate extant definitions in their respective literatures (intuition, sensemaking) into one synthesizing definition and, by analyzing definitions of heuristics from extant studies, found that most authors use one or more of four common features:

(1) the frugal use of resources (time, effort, information, attention, or processing capacity),

(2) the "good enough" effectiveness,

(3) the ill-defined, difficult problem which they solve and

(4) the opposition with complex, analytical algorithms.

These features describe extant literature's view on heuristics as tools to address a certain type of problem (complex and ill-defined) in a certain way (faster and cheaper than complex 
algorithms) and with a certain expectation (not optimizing). To conclude, this paper proposes a definition that includes all four main attributes:

Managerial heuristics are cognitive shortcuts for making decisions, that use fewer resources than analytical algorithms in order to reach good enough solutions for difficult managerial problems.
Lifecycle of heuristics as managerial proverbs

\subsection{Intentionality and its link with three theoretical approaches}

Three main theoretical approaches can be distinguished in the literature on heuristics (Bingham and Eisenhardt, 2014): the heuristics-and-biases approach, the fast-and-frugal approach, and the simple-rules approach.

The heuristics-and-biases approach, initiated by Amos Tversky and Daniel Kahneman, studies systematic heuristics like representativeness, availability, anchoring, and base-rate neglect (Kahneman and Tversky, 1996; Kahneman, 2012; Tversky and Kahneman, 1973, 1974). This theoretical approach recognizes the efficiency of heuristics as a result of the accuracy/effort trade-off while emphasizing their fallibility as bias- and error-inducing. The fast-and-frugal approach, led by the work of Gerd Gigerenzer and his collaborators, looks at heuristics as useful, adaptive tools of the mind and deny the generality of the accuracy/effort trade-off (Gigerenzer, 1996; Gigerenzer and Gaissmaier, 2011; Gigerenzer and Goldstein, 1996; Gigerenzer et al., 1999), emphasizing instances where simple heuristics are more accurate than complex algorithms (De Miguel et al., 2009; Gigerenzer, 2008; Luan et al., 2019; Wübben and Wangenheim, 2008). The simple-rules approach, advanced by Kathleen Eisenhardt and Christopher Bingham, looks beyond the immediate outcome of heuristics in decision-making and documents how intentional, articulated and shared heuristics are key strategic tools at organizational level (Bingham and Eisenhardt, 2011, 2014; Bingham et al., 2007; Bingham and Haleblian, 2012; Eisenhardt and Sull, 2001).

Many theorists identify two main classes of heuristics, but use different labels for this taxonomy. Mousavi and Gigerenzer (2014) differentiate unconscious heuristics developed over the course of human evolution from conscious heuristics that are developed by direct learning. Chow (2015) opposes inferential heuristics that people employ without knowing, are immune to experience, are systemic (common among everyone) and may be innate, from methodological heuristics that are used consciously and deliberately, are cultivated by experience, and vary between individuals. Guercini (2012, p. 2016) observes that heuristics can be "neurobiological in origin, in that they are inherent in cognitive processes, which are bound by the brain's structure and functioning" or "cultural in origin, or in any event, the product of learning." Basel and Brühl (2013) observe the existence of two types of heuristics, which they link to the two systems of thought described by dual-process theories.

Despite the different labels, all these scholars describe in fact the same two categories. Their respective attributes are organized in Table 1 . The feature that can discriminate easier is the deliberate/non-deliberate use. Intent (deliberate or not) and awareness (conscious or not) are similar concepts, but not identical. We may be aware that we have a pulse, but we do not

Unintentional heuristics

(1) unconscious, employed without knowing

(2) developed by evolution, innate, inherent, neurobiological in origin

(3) systemic, common among everyone

(4) System 1
Intentional heuristics

(1) used consciously and deliberately

(2) developed by direct learning, cultivated by experience, cultural in origin

(3) non-systemic, vary between individuals

(4) System 2
Table 1.

Intentional and unintentional heuristics as described in literature 
have it purposefully. Origin and idiosyncrasy are important features, but less useable in analyses. This paper proposes, therefore, to aggregate all these taxonomies into a coherent and well-defined one that differentiates between unintentional and intentional heuristics.

Based on the attributes aggregated in Table 1, this paper proposes that

Intentional heuristics are idiosyncratic heuristics that are learned from experience and employed consciously and purposefully,

while

Unintentional heuristics are systemic, inherent or innate heuristics, that are used in a nondeliberate way.

There is a link between these two categories of heuristics and the three theoretical approaches. Basel and Brühl (2013) show that the heuristics-and-biases school exclusively studies unintentional heuristics. Bingham and Eisenhardt (2014) go a step further by mapping all three streams of research on these two categories: "heuristics-and-biases focuses on universal heuristics that are automatically invoked and can lead to biased processes," "fast-and-frugal centers on universal heuristics that are automatic, but that also exploit the environment to achieve accurate predictions," while "simple rules are idiosyncratic heuristics that are often consciously understood (...) and can constitute strategy" (Bingham and Eisenhardt, 2014, p. 1698). While their assignment of the heuristics-and-biases program to unintentional heuristics and of the simple-rules program to intentional heuristics is beyond debate, I venture that the fast-and-frugal approach does not exclusively address unintentional (universal, automatic) heuristics. One of the most compelling examples of a simple heuristic that outperforms complex algorithms is the case, recounted by Gigerenzer (2008), of Nobel laureate Harry Markowitz. After developing a complex method (meanvariance portfolio method) to allocate investments across assets, Markowitz ignored it and allocated his own pension funds equally across a few funds, using the simple $1 / \mathrm{N}$ heuristic. In this case, the use of $1 / \mathrm{N}$ cannot be said to be automatic. Moreover, Gigerenzer (2008, p. 23) affirms that one of the main goals of researching heuristics is to "design heuristics and/or environments that teach and improve decision making in fields such as health care, law, and politics," which implies that a large area of research for the fast-and-frugal approach covers intentional heuristics.

While the link between intentionality and the three streams of research is clear at the theoretical level, few empirical papers acknowledge the stream they belong to or the category of heuristics they study. In the first step of the analysis, this paper will map extant empirical research on heuristics against intentionality, clarifying the characteristics of the research object for the three theoretical approaches. Given the completely different nature of intentional and unintentional heuristics, the author also calls on researchers of heuristics to clearly state in their papers which kind of heuristic they study. Aside from increased accuracy, this approach may as well untangle the current debate on the topic of heuristic efficacy.

The next chapters answer several calls for research on how intentional managerial heuristics emerge. Atanasiu and Ruotsalainen (2019) showed that less than $8 \%$ of empirical studies on heuristics are concerned with how managers create their heuristics, the vast majority of extant research focusing on documenting the usage of a certain heuristic or on evaluating its outcome. However, several scholars have called for heuristics researchers to focus on "how individual-specific heuristics may evolve into firm-level heuristics" (Maitland and Sammartino, 2015, p. 1,575) and on "better understanding their sources and evolution" (Ott et al., 2017, p. 320). The main purpose of this study is to answer these calls by further developing a theory-based process model for the emergence of managerial heuristics. 


\section{Methods for developing the framework}

This paper employs a three-step approach for proposing a process model for the emergence of managerial heuristics. The first two steps will be treated in this section: step one uses a systematic review of empirical studies on heuristics in order to map extant research on four key criteria and to obtain the four static stages of the process; step two adapts a knowledge management framework to yield the four dynamic processes.
Lifecycle of heuristics as managerial proverbs

\subsection{Identifying the four stages of the process}

As a first step, this paper uses a systematic review approach to organize empirical studies on heuristics. For this, it employs methods characteristic to systematic literature reviews (Palmatier et al., 2017): clear criteria for including a paper in the sample, replicable search methods for identifying the relevant papers, coherent employment of the mentioned criteria to select the relevant papers into the sample, and unitary analysis tools to analyze the resulting sample. However, the current analysis differs from a systematic literature review as, after relying on the sample of studies for the first step of the analysis, it further develops the model using insights from papers in the sample, but also from other research and other literatures.

The sample includes only empirical studies, as it needs to examine and analyze real examples of heuristics against specific criteria: intentionality, articulation, sharing, and adoption detailed further below. Non-empirical studies are valuable to guide the third step of this analysis, but, despite their clear descriptions of heuristic structure (Gigerenzer and Brighton, 2009) or mechanism (Shah and Oppenheimer, 2008), they lack real examples of heuristics to be included in the analysis.

In the scientific literature, the term heuristic is not specific to Management and Organizational Science (MOS), but is employed voraciously by a large number of related (Operations Research, etc.) or unrelated fields (Engineering, Machine Learning, etc.). To overcome this obstacle, several combinations of words were employed in several consecutive searches of three databases. On Web of Science, I ran three searches: for heuristic* in titles, for heuristic* managerial decision-making in titles, abstracts, and keywords, and for simple rules in titles, abstracts, and keywords. I searched papers published between 1999 and 2020 and further refined each sample by Management and then excluded everything except Management, Business, and Psychology. The inclusion of Psychology is necessary, as most concepts originate in this field and seminal papers were published in Psychology journals. In SCOPUS I ran a search for heuristic* AND managerial AND decision-making in papers published in the same period, 1999-2020, and further refined for Business and Psychology and then excluded everything else. To widen my exploration, I also searched in Google Scholar for "heuristics" or "simple rules" and "managerial decision-making" and added the first 50 results to the analysis. All these searches resulted in an initial sample of 206 papers. I manually excluded papers that use the term heuristic as an adjective (e.g., heuristic model, heuristic algorithm, heuristic transfer), papers regarding Critical Systems Heuristics and the Fairness Heuristic Theory, papers from logistics research, operations research, machine learning, and modelling that reached the sample despite the automatic refining and excluding in the previous step, and papers using the term meta-heuristics. Further, after reading abstracts, I manually excluded papers that were not about heuristics (for example, influenced by the heuristics-and-biases school, some authors use the expression heuristics and biases to describe cognitive biases), non-empirical papers (conceptual, literature reviews, but also interviews, books, and from-the-editor articles), papers in which the authors proposed their own heuristic, master theses, and two papers I could not retrieve. This process led to a final sample of 49 empirical papers on heuristics published between 1999 and 2020 presented in Table 2. 
MD

59,7

1622

Table 2.

Heuristics in empirical studies organized by intentionality, articulation, sharing, and adoption

\begin{tabular}{|c|c|c|c|c|c|c|}
\hline Paper & Domain & Heuristics & $\begin{array}{c}\text { Intent } \\
\text { Unintentional/ } \\
\text { Intentional }\end{array}$ & $\begin{array}{l}\text { Articulation } \\
\text { Non- } \\
\text { articulated/ } \\
\text { Articulated }\end{array}$ & $\begin{array}{c}\text { Sharing } \\
\text { Manager } \\
\text { level/ } \\
\text { Shared }\end{array}$ & $\begin{array}{l}\text { Adoption } \\
\text { Optional/ } \\
\text { Policy }\end{array}$ \\
\hline $\begin{array}{l}\text { Ambos et al., } \\
2020\end{array}$ & internationalization & $\begin{array}{l}\text { representativeness, } \\
\text { availability }\end{array}$ & $\mathrm{U}$ & $\mathrm{N}$ & $\mathrm{M}$ & $\mathrm{N} / \mathrm{A}$ \\
\hline $\begin{array}{l}\text { Bateman and } \\
\text { et al., } 2017\end{array}$ & retirement plans & $\begin{array}{l}\text { default heuristic, } \\
1 / \mathrm{N}\end{array}$ & $\mathrm{U}$ & $\mathrm{N}$ & $\mathrm{M}$ & $\mathrm{N} / \mathrm{A}$ \\
\hline $\begin{array}{l}\text { Caramelli } \\
\text { and Carberry, } \\
2016\end{array}$ & $\begin{array}{l}\text { investing in } \\
\text { company stock }\end{array}$ & $\begin{array}{l}\text { representativeness, } \\
\text { familiarity }\end{array}$ & $\mathrm{U}$ & $\mathrm{N}$ & $\mathrm{M}$ & $\mathrm{N} / \mathrm{A}$ \\
\hline Chen, 2017 & where to invest & availability & $\mathrm{U}$ & $\mathrm{N}$ & $\mathrm{M}$ & $\mathrm{N} / \mathrm{A}$ \\
\hline $\begin{array}{l}\text { Devers et al., } \\
2007\end{array}$ & $\begin{array}{l}\text { buy or sell stock } \\
\text { option }\end{array}$ & $\begin{array}{l}\text { endowment effect, } \\
\text { loss aversion }\end{array}$ & $\mathrm{U}$ & $\mathrm{N}$ & $\mathrm{M}$ & N/A \\
\hline $\begin{array}{l}\text { Eberhart and } \\
\text { Naderer, } \\
2017 \\
\end{array}$ & $\begin{array}{l}\text { to choose eco } \\
\text { products }\end{array}$ & greenwashing & $\mathrm{U}$ & $\mathrm{N}$ & $\mathrm{M}$ & $\mathrm{N} / \mathrm{A}$ \\
\hline $\begin{array}{l}\text { Eriksson and } \\
\text { Kadefors, } \\
2017 \\
\end{array}$ & rail project design & $\begin{array}{l}\text { availability, } \\
\text { familiarity }\end{array}$ & $\mathrm{U}$ & $\mathrm{N}$ & $\mathrm{M}$ & $\mathrm{N} / \mathrm{A}$ \\
\hline $\begin{array}{l}\text { Graffin et al., } \\
2013\end{array}$ & $\begin{array}{l}\text { early evaluation of } \\
\text { a CEO }\end{array}$ & $\begin{array}{l}\text { anchoring, halo } \\
\text { effect }\end{array}$ & $\mathrm{U}$ & $\mathrm{N}$ & $\mathrm{S}$ & $\mathrm{N} / \mathrm{A}$ \\
\hline $\begin{array}{l}\text { Hutchinson } \\
\text { et al., } 2010\end{array}$ & budget allocation & $\begin{array}{l}\text { anchoring and } \\
\text { adjusting }\end{array}$ & $\mathrm{U}$ & $\mathrm{N}$ & $\mathrm{M}$ & $\mathrm{N} / \mathrm{A}$ \\
\hline $\begin{array}{l}\text { Jayakumar, } \\
2016\end{array}$ & consumer behavior & $\begin{array}{l}\text { availability and } \\
\text { others }\end{array}$ & $\mathrm{U}$ & $\mathrm{N}$ & $\mathrm{M}$ & $\mathrm{N} / \mathrm{A}$ \\
\hline $\begin{array}{l}\text { Johnson and } \\
\text { Tellis, } 2005\end{array}$ & stock trading & $\begin{array}{l}\text { hot hand and } \\
\text { gambler's fallacy }\end{array}$ & $\mathrm{U}$ & $\mathrm{N}$ & $\mathrm{M}$ & $\mathrm{N} / \mathrm{A}$ \\
\hline Macchi, 2000 & statistical inference & base rate fallacy & $\mathrm{U}$ & $\mathrm{N}$ & $\mathrm{M}$ & $\mathrm{N} / \mathrm{A}$ \\
\hline $\begin{array}{l}\text { Martin et al., } \\
2016\end{array}$ & $\begin{array}{l}\text { CEO temporal } \\
\text { orientation }\end{array}$ & $\begin{array}{l}\text { loss aversion, } \\
\text { anchoring }\end{array}$ & $\mathrm{U}$ & $\mathrm{N}$ & $\mathrm{M}$ & $\mathrm{N} / \mathrm{A}$ \\
\hline $\begin{array}{l}\text { Miller and } \\
\text { Shapira, } 2004\end{array}$ & option valuation & $\begin{array}{l}\text { loss aversion, } \\
\text { mental accounting }\end{array}$ & $\mathrm{U}$ & $\mathrm{N}$ & $\mathrm{M}$ & $\mathrm{N} / \mathrm{A}$ \\
\hline $\begin{array}{l}\text { Newell et al., } \\
2003\end{array}$ & $\begin{array}{l}\text { choice between } 2 \\
\text { shares }\end{array}$ & take the best & $\mathrm{U}$ & $\mathrm{N}$ & $\mathrm{M}$ & $\mathrm{N} / \mathrm{A}$ \\
\hline $\begin{array}{l}\text { Pham and } \\
\text { Avnet, } 2009\end{array}$ & voting on Survivor & affect heuristics & $\mathrm{U}$ & $\mathrm{N}$ & $\mathrm{M}$ & $\mathrm{N} / \mathrm{A}$ \\
\hline Phillips, 2017 & $\begin{array}{l}\text { baseball } \\
\text { management }\end{array}$ & $\begin{array}{l}\text { sensitivity to round } \\
\text { numbers }\end{array}$ & $\mathrm{U}$ & $\mathrm{N}$ & $\mathrm{M}$ & $\mathrm{N} / \mathrm{A}$ \\
\hline $\begin{array}{l}\text { Rusetsky, } \\
2014\end{array}$ & pricing & $\begin{array}{l}\text { anchoring and } \\
\text { adjusting }\end{array}$ & $\mathrm{U}$ & $\mathrm{N}$ & $\mathrm{M}$ & N/A \\
\hline Tsay, 2014 & $\begin{array}{l}\text { assessing } \\
\text { orchestras }\end{array}$ & visual cues & $\mathrm{U}$ & $\mathrm{N}$ & $\mathrm{M}$ & $\mathrm{N} / \mathrm{A}$ \\
\hline
\end{tabular}




\begin{tabular}{|c|c|c|c|c|c|c|}
\hline \multicolumn{2}{|l|}{$\begin{array}{l}\text { Tseng and } \\
\text { Yang, } 2011\end{array}$} & \multirow{2}{*}{\begin{tabular}{|l|} 
representativeness \\
more sensitivity to \\
the probability of \\
winning than to the \\
amount
\end{tabular}} & \multirow{2}{*}{$\begin{array}{l}\mathrm{U} \\
\mathrm{U}\end{array}$} & \multirow{2}{*}{$\begin{array}{l}\mathrm{N} \\
\mathrm{N}\end{array}$} & \multirow{2}{*}{\begin{tabular}{|l|}
$\mathrm{M}$ \\
$\mathrm{M}$ \\
\end{tabular}} & \multirow{2}{*}{$\begin{array}{l}\text { N/A } \\
\text { N/A }\end{array}$} \\
\hline $\begin{array}{l}\text { Venkatraman } \\
\text { et al., } 2014\end{array}$ & complex gambles & & & & & \\
\hline $\begin{array}{l}\text { Wickham, } \\
2003\end{array}$ & $\begin{array}{l}\text { estimating } \\
\text { entrepreneurial } \\
\text { success }\end{array}$ & representativeness & $\mathrm{U}$ & $\mathrm{N}$ & $\mathrm{M}$ & N/A \\
\hline $\begin{array}{l}\text { Bauer et al., } \\
2013\end{array}$ & $\begin{array}{l}\text { customer } \\
\text { management } \\
\text { prediction }\end{array}$ & $\begin{array}{l}\text { ignore unimportant } \\
\text { criteria }\end{array}$ & $\mathrm{I}$ & $\mathrm{N}$ & $\mathrm{M}$ & N/A \\
\hline $\begin{array}{l}\text { Burlinson et } \\
\text { al., } 2018\end{array}$ & $\begin{array}{l}\text { to adopt a heating } \\
\text { scheme }\end{array}$ & payback period & $\mathrm{I}$ & $\mathrm{N}$ & $\mathrm{M}$ & N/A \\
\hline Hauser, 2014 & $\begin{array}{l}\text { choosing from a } \\
\text { consideration set }\end{array}$ & fast and frugal & $\mathrm{I}$ & $\mathrm{N}$ & $\mathrm{M}$ & N/A \\
\hline $\begin{array}{l}\text { Luan et al., } \\
2019\end{array}$ & hiring & $\Delta$-inference & $\mathrm{I}$ & $\mathrm{N}$ & $\mathrm{M}$ & N/A \\
\hline $\begin{array}{l}\text { Persson and } \\
\text { Ryals, } 2014\end{array}$ & $\begin{array}{l}\text { customer } \\
\text { management }\end{array}$ & hiatus & I & $\mathrm{N}$ & $\mathrm{M}$ & N/A \\
\hline $\begin{array}{l}\text { Schiffels et } \\
\text { al., } 2018\end{array}$ & knapsack problem & $\begin{array}{l}\text { maximum ratio of } \\
\text { value to resource } \\
\text { requirement not } \\
\text { exceeding the } \\
\text { capacity }\end{array}$ & $\mathrm{I}$ & $\mathrm{N}$ & $\mathrm{M}$ & N/A \\
\hline $\begin{array}{l}\text { Stewart and } \\
\text { Patterson, } \\
2016\end{array}$ & $\begin{array}{l}\text { behaviour in the } \\
\text { classroom }\end{array}$ & $\begin{array}{l}\text { take risks because } \\
\text { mistakes are } \\
\text { essential to } \\
\text { learning. }\end{array}$ & I & $\mathrm{N}$ & $\mathrm{M}$ & N/A \\
\hline $\begin{array}{l}\text { Turturea, } \\
2018\end{array}$ & $\begin{array}{l}\text { crowdfunding } \\
\text { investing }\end{array}$ & $\begin{array}{l}\text { confirmatory and } \\
\text { disconfirmatory } \\
\text { heuristics }\end{array}$ & $\mathrm{I}$ & $\mathrm{N}$ & $\mathrm{M}$ & N/A \\
\hline $\begin{array}{l}\text { West et al., } \\
2017\end{array}$ & $\begin{array}{l}\text { what work to } \\
\text { present to clients }\end{array}$ & $\begin{array}{l}\text { the work with the } \\
\text { highest number of } \\
\text { favorable aspects }\end{array}$ & $\mathrm{I}$ & $\mathrm{N}$ & $\mathrm{M}$ & N/A \\
\hline Bryant, 2007 & $\begin{array}{l}\text { how to deal with } \\
\text { opportunities }\end{array}$ & $\begin{array}{l}\text { take opportunities } \\
\text { that have a high } \\
\text { degree of fit with } \\
\text { core strategy }\end{array}$ & I & $\mathrm{A}$ & $\mathrm{M}$ & N/A \\
\hline $\begin{array}{l}\text { Guercini et } \\
\text { al., } 2015\end{array}$ & $\begin{array}{l}\text { how to conduct a } \\
\text { sales meeting }\end{array}$ & $\begin{array}{l}\text { if things go wrong, } \\
\text { stop and } \\
\text { reschedule a new } \\
\text { meeting }\end{array}$ & $\mathrm{I}$ & A & $\mathrm{M}$ & N/A \\
\hline
\end{tabular}

Lifecycle of heuristics as managerial proverbs

1623

Table 2. 
MD

59,7

1624

\begin{tabular}{|c|c|c|c|c|c|c|}
\hline $\begin{array}{l}\text { Maitland and } \\
\text { Sammartino, } \\
2015\end{array}$ & Internationalization & $\begin{array}{l}\text { if hazard is smaller } \\
\text { than current host } \\
\text { country, we can } \\
\text { proceed }\end{array}$ & I & A & $\mathrm{M}$ & N/A \\
\hline $\begin{array}{l}\text { Roch et al., } \\
2000\end{array}$ & $\begin{array}{l}\text { distribution of } \\
\text { resources }\end{array}$ & $1 / \mathrm{N}$ & I & A & $\mathrm{M}$ & N/A \\
\hline Sayed, 2016 & $\begin{array}{l}\text { target price } \\
\text { forecast }\end{array}$ & $\begin{array}{l}\text { Price to Earnings } \\
\text { (vs DCF) }\end{array}$ & I & A & M & N/A \\
\hline $\begin{array}{l}\text { Baker and } \\
\text { Collier, } 1999\end{array}$ & allocation of rooms & $\begin{array}{l}\text { first come, first } \\
\text { served }\end{array}$ & I & A & S & $\mathrm{O}$ \\
\hline $\begin{array}{l}\text { Barberà- } \\
\text { Mariné et al., } \\
2019\end{array}$ & $\begin{array}{l}\text { patient triage } \\
\text { scenarios }\end{array}$ & $\begin{array}{l}\text { when the patient } \\
\text { has a certain age, I } \\
\text { assign a high } \\
\text { priority code to } \\
\text { prevent the patient } \\
\text { from getting tired } \\
\text { and waiting too } \\
\text { much }\end{array}$ & I & $\mathrm{A}$ & S & $\mathrm{O}$ \\
\hline $\begin{array}{l}\text { Eriksson and } \\
\text { Kadefors, } \\
2017\end{array}$ & rail project design & $\begin{array}{l}\text { catch phrases - } \\
\text { mantras }\end{array}$ & I & A & S & $\mathrm{O}$ \\
\hline $\begin{array}{l}\text { Merlo et al., } \\
2008\end{array}$ & marketing & $\begin{array}{l}\text { percent of } \\
\text { expected sales }\end{array}$ & I & A & S & $\mathrm{O}$ \\
\hline $\begin{array}{l}\text { Meszaros, } \\
1999\end{array}$ & $\begin{array}{l}\text { reducing the } \\
\text { chances of } \\
\text { accidents }\end{array}$ & $\begin{array}{l}\text { survivability, } \\
\text { alternative } \\
\text { solution, upward } \\
\text { appeal, } \\
\text { affordability }\end{array}$ & I & A & S & $\mathrm{O}$ \\
\hline $\begin{array}{l}\text { Monaghan } \\
\text { and } \\
\text { Tippmann, } \\
2018 \\
\end{array}$ & Internationalization & $\begin{array}{l}\text { choose location } \\
\text { because skill sets } \\
\text { are within reach }\end{array}$ & I & A & $S$ & $\mathrm{O}$ \\
\hline $\begin{array}{l}\text { Oliver and } \\
\text { Roos, } 2005\end{array}$ & various & $\begin{array}{l}\text { hire enthousiastic } \\
\text { and intelligent } \\
\text { individuals over } \\
\text { those with specific } \\
\text { skills or } \\
\text { experience. }\end{array}$ & I & A & S & $\mathrm{O}$ \\
\hline $\begin{array}{l}\text { Wübben and } \\
\text { Wangenheim, } \\
2008\end{array}$ & $\begin{array}{l}\text { consider customers } \\
\text { active/inactive }\end{array}$ & hiatus heuristic & I & $\mathrm{A}$ & S & $\mathrm{O}$ \\
\hline $\begin{array}{l}\text { Bingham and } \\
\text { Eisenhardt, } \\
2011\end{array}$ & internationalization & $\begin{array}{l}\text { restrict } \\
\text { internationalization } \\
\text { to English- } \\
\text { speaking markets }\end{array}$ & I & A & S & $\mathrm{P}$ \\
\hline $\begin{array}{l}\text { Bingham et } \\
\text { al., } 2007\end{array}$ & internationalization & $\begin{array}{l}\text { enter one country } \\
\text { at a time }\end{array}$ & I & A & S & $\mathrm{P}$ \\
\hline
\end{tabular}

Table 2. 


\begin{tabular}{|l|l|l|l|l|l|l|}
\hline $\begin{array}{l}\text { Bingham } \text { et } \\
\text { al., } 2019\end{array}$ & internationalization & $\begin{array}{l}\text { enter countries } \\
\text { with lots of } \\
\text { pharma activity } \\
\text { and where rich } \\
\text { pharma firms had } \\
\text { headquarters }\end{array}$ & I & A & P \\
\hline $\begin{array}{l}\text { Kazakova } \\
\text { and Geiger, } \\
2015\end{array}$ & business strategy & $\begin{array}{l}\text { if } 10 \% \text { of } \\
\text { customers say yes, } \\
\text { then you have your } \\
\text { target group }\end{array}$ & I & A & S & P \\
\hline $\begin{array}{l}\text { Kazakova, } \\
2015\end{array}$ & business strategy & $\begin{array}{l}\text { promote short } \\
\text { offers in Facebook, } \\
\text { long-term offers on } \\
\text { the website. }\end{array}$ & I & A & S & P \\
\hline $\begin{array}{l}\text { Suarez and } \\
\text { Montes, } 2019\end{array}$ & Everest & $\begin{array}{l}\text { climbing see a } \\
\text { damaged rope, you } \\
\text { have to fix it right } \\
\text { away }\end{array}$ & I & A & S & P \\
\hline
\end{tabular}

Lifecycle of heuristics as managerial proverbs

1625

The resulting sample of papers has been analyzed against four criteria. As unintentional heuristics are systemic, inherent or innate (please refer to the synthesized definition in Section 2.3), they do not emerge. The focus of this paper is to map and describe the process of how managerial heuristics emerge, so it follows that its research object is the intentional heuristic. Therefore, in this current literature review, papers on heuristics should be initially split between unintentional and intentional heuristics.

Criterion 1 - Intentionality. As detailed in subsection 2.3, heuristics can be unintentional (unconscious, systemic, inherent or innate) or intentional (conscious, idiosyncratic, learned from experience, and employed purposefully). This first criterion split the sample into 22 papers that describe unintentional heuristics and 28 papers that describe intentional heuristics (one paper, Eriksson and Kadefors, 2017, describes both kinds, so it is present in both subsamples).

From this point of view, the first insight is that, indeed, with few exceptions, unintentional heuristics described in extant studies are those identified by the heuristics-and-biases school: availability, anchoring, representativeness, loss aversion, base rate neglect, mental accounting, default, endowment effect. In the meantime, intentional heuristics differ in each study. This observation supports empirically the theoretical proposition that unintentional heuristics are systemic, while intentional heuristics are idiosyncratic.

By further analyzing the heuristics described in these empirical studies, I observed that they differ in other aspects, as well. Some heuristics are enacted by the subjects without being clearly formulated, while in others the researchers can quote their articulation; some heuristics are described as being used at the individual level of the manager, others are shared and enacted at group or organizational level; finally, shared heuristics can be implemented as an optional guideline or as policy. This led to analyzing the sample against three more criteria: articulation, sharing, and adoption.

Criterion 2 -Articulation. I coded as articulated heuristics those that are described verbatim (example: If things go wrong, stop and reschedule a new meeting from Guercini et al., 2015) or paraphrased by the author (example: Enter countries with lots of pharma activity and where rich pharma firms had headquarters, from Bingham et al., 2019) and as non-articulated heuristics those that are enacted without being put into words. 
$\mathrm{MD}$

59,7

1626

Criterion 3 - Sharing. The heuristics described in the sample papers are described at the individual level of the manager or shared at group or organization level. Assigning heuristics and studies to one of these categories was done after inferring it from the context or when the author/s clearly state the level of analysis. For example, Bingham and Eisenhardt (2011) analyze organizational heuristics and specify that "the fact that multiple informants indicated the same lesson learned from experience reflects a collective understanding independent of a specific individual" (Bingham and Eisenhardt, 2011, p. 1443).

Criterion 4-Adoption. The heuristics that are described at group or organization level are either adopted as optional guidelines or fully adopted as policy.

In Table 2 the papers are purposefully not in alphabetical order, but arranged so that the findings are especially evident. Different shades of gray in the coding section emphasize the subsamples. Where multiple examples of heuristics were offered in a paper, only one was selected for illustration. Table 3 organizes the steps of this systematic literature review.

Although the main focus is intentional heuristics, the analysis on articulation, sharing and adoption has been made for the entire sample. All unintentional heuristics are non-articulated (a reasonable finding, while they are unconscious) and, with one exception, enacted at individual level (Graffin et al., 2013, describe how boards are anchored by the image of the former $\mathrm{CEO}$ when they evaluate the new $\mathrm{CEO}$ ). It is curious that only this one unintentional heuristic has been described as enacted at group level, as unintentional heuristics are shown to be systemic (Bateman et al., 2017), which opens the possibility of groups and organizations to act in a coherent manner based on the same unintentional heuristic. Perhaps extant heuristics-and-biases research has focused more on the individual level, which prompts the call for future studying unintentional heuristics at group and organizational level.

Intentional heuristics, on the other hand, can be either non-articulated or articulated, which implies that intentional heuristics may evolve from non-articulated to articulated. A heuristic needs then to be articulated in order to be shared, supporting the claim that heuristics are not subject to tacit transfer of knowledge (Nonaka, 1994). Articulated heuristics are captured at either individual manager level or shared at group or organization level, which also supports a dynamic view in which articulated heuristics may further evolve from individual to shared. The possibility that some heuristics are generated and enacted directly at group level is discussed in a future section.

In conclusion, while unintentional heuristics are non-articulated and individual, the main research object of this analysis, intentional heuristics, are captured in four stages: non-articulated, articulated, shared and institutionalized. These four stages, described as static by various papers in the sample, allude to a dynamic process model of an intentional heuristic from being generated as non-articulated to being articulated, then to being shared to the organization, and then to being adopted either as an optional guideline or as policy. A framework on how these stages evolve will be proposed in the next subsection.

\subsection{Identifying a dynamic framework}

As a second step, this paper chooses and adapts an extant framework to include, connect and explain the four stages. Intentional heuristics are pieces of knowledge that are learned from experience (Bingham and Eisenhardt, 2011; Bingham and Haleblian, 2012) and can be subsequently used in similar situations. The way they emerge can, therefore, be described using tools proposed by the literature on organizational learning or the literature on knowledge management. I, therefore, searched organizational learning and knowledge management literatures for compatible models. After examining prominent extant frameworks and investigating what other research has analyzed and used, the best fit is identified in the research conducted by Kai Mertins, Peter Heisig and Jens Vorbeck (in Mertins et al., 2003), a comprehensive survey of the German TOP 1000 and European TOP 
Step 1: Five searches in three databases:

Step 2: Manual exclusion criteria

Step 3: Analysis
Search No. 1: On Web of Science for heuristic* in titles, papers published between 1999 and 2020, further refined each sample by Management and then excluded everything except Management, Business, and Psychology Search No. 2: On Web of Science for heuristic* managerial decision-making in titles, abstracts, and keywords, papers published between 1999 and 2020, further refined each sample by Management and then excluded everything except Management, Business, and Psychology

Search No. 3: On Web of Science for simple rules in titles, abstracts, and keywords, papers published between 1999 and 2020, further refined each sample by Management and then excluded everything except Management, Business, and Psychology

Search No. 4: In SCOPUS for heuristic* AND managerial AND decisionmaking in papers published between 1999-2020, further refined for Business and Psychology and then excluded everything else

Search No. 5: In Google Scholar, for "heuristics" or "simple rules" and

"managerial decision-making" and added the first 50 results to the analysis

The results of all these searches made up an initial sample of 206 papers

(1) papers that use the term heuristic as an adjective (for example heuristic model, heuristic algorithm, heuristic transfer)

(2) papers regarding Critical Systems Heuristics and the Fairness Heuristic Theory

(3) papers from logistics research, operations research, machine learning, and modelling that reached the sample despite the automatic refining and excluding in the previous step

(4) papers using the term meta-heuristics

(5) papers that were not about heuristics (for example, influenced by the heuristics-and-biases school, some authors use the expression heuristics and biases to describe cognitive biases)

(6) non-empirical papers (conceptual, literature reviews, but also interviews, books, and from-the-editor articles)

(7) papers in which the authors proposed their own heuristic

(8) master theses

(9) two papers I could not retrieve

This process led to a final sample of 49 empirical papers

Where multiple examples of heuristics were offered in a paper, only one was selected for illustration, with mentioning its domain of application. Then, the sample was organized on three criteria:
(1) Intent
(2) Articulation
(3) Sharing
(4) Adoption

Lifecycle of heuristics as managerial proverbs (n) 
$\mathrm{MD}$

59,7

1628
Figure 1.

The process model of heuristic emergence
The choice of this framework is also supported by the analysis of Ranjbarfard et al. (2014) of multiple models from organizational learning and knowledge management that concludes with the choice of the Mertins et al. (2003) as the best framework for empirical integration. In their review, McClory et al. (2017) also use the same framework for conceptualizing the lessons-learned process. Choosing a framework for heuristics from knowledge management is also supported by the work of numerous theorists who link the two literatures (Hazlett et al., 2005; Maqsood et al., 2004). Tsoukas and Vladimirou (2001, as cited in Hazlett et al., 2005) even identify in their definition of the domain the emergence of heuristic knowledge as a key process of knowledge management.

\section{Toward a theory-based process model of how heuristics emerge}

In the third, descriptive step of our approach, treated in this current section, this paper assembles the previous findings into a graphical process model and uses insights from literature to illustrate and enrich the description of the model and to synthesize four propositions. As depicted in Figure 1, the four stages resulted from the literature review non-articulated, articulated, shared and institutionalized - fit well with the adapted framework from Mertins et al. (2003) - generation, articulation, sharing and application to outline a process model of heuristic emergence.

This section further develops this model by looking at the origin of heuristics, by detailing the articulation process, by exploring the ways heuristics are shared, and by describing the two paths of application. The theory-based approach continues in a non-systematic way, by examining extant literature on heuristics and by combining lenses from close (organizational learning, knowledge management, sensemaking) and far apart (paremiology, the science of proverbs) areas of research (Okhuysen and Bonardi, 2011). The abandoning of the systematic approach is mainly caused by the limited number of empirical studies on intentional heuristics, which results in some processes being captured in very few papers, making it impossible for clear categories to emerge. This prompted the analysis of as many studies as possible, beyond the initial sample, to gain granularity and richness for the description of the processes.

Because heuristics and proverbs belong to the same family, this paper employs a blendedtheory approach to infer how heuristics emerge by studying how proverbs do. Articulated heuristics are, like proverbs, short, catchy, generic decision rules. Like heuristics (Forbes et al., 2015), proverbs are inductive in nature (Shapin, 2001); like heuristics (Bingham and Eisenhardt, 2011), proverbs are born from experience - "experience has generally provided the evidence on which people base folk lore" (Will and Hardaway, 1994, p. 81); like heuristics (Chow, 2015), proverbs are satisficing - "proverbs are aids to action not in the domain of reason, but of reasonableness" (Shapin, 2001, p. 740). Heuristics are ecologically fit (Gigerenzer, 2008, 2016; Gigerenzer and Brighton, 2009; Gigerenzer and Gaissmaier, 2011; Hafenbrädl et al., 2016; Mousavi et al., 2017), they are adapted to the context and environment out of which and for which they have been generated. Likewise, "the meaning of a proverb is made clear only when, side by side with the translation, is given a full account of the accompanying social situation - the reason for its use, its effect, and its significance in speech" (Firth, 1926; as cited by Shapin, 2001, p. 745). Sometimes, heuristics really are proverbs. Manimala (1992) gathered a collection of 186 heuristics used by entrepreneurs and a lot of

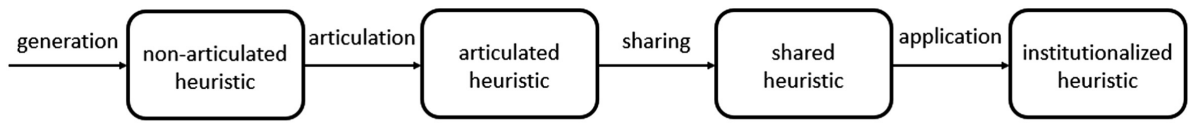

Source(s): Adapted from Mertins et al. (2003) 
these are, in fact, proverbs: Don't put all your eggs in one basket, or play on existing proverbs: Timing is money. Like heuristics, proverbs are strategies for dealing with situations (Shapin, 2001). Real-life management practice employs many such simple rules and most managers use a number of articulated, proverb-like heuristics, for example, Sell in May and go away as a guideline for investing (Bouman and Jacobsen, 2002). The analogy between articulated heuristics and proverbs will be used further in this paper for describing the mechanisms behind the generation, articulation and sharing of heuristics.
Lifecycle of heuristics as managerial proverbs

1629

\subsection{Generation}

Heuristics are generated as lessons learned from negative outcomes. Eisenhardt and Bingham (2017) and Ott et al. (2017) theorize that strategizing can be achieved by doing and then correcting course based on outcome and by thinking, planning ahead and creating models and scenarios. Both studies identify heuristics as important tools for strategy building by doing, emerging as lessons from experience. The genesis of intentional heuristics is, therefore, a part of managerial and organizational learning (Bingham and Eisenhardt, 2011) and results from experience: "all the respondents concurred that the foundation is previous professional experience” (Guercini et al., 2015, p. 32). Managers and firms most often learn from negative outcomes (Bingham and Haleblian, 2012) and mistakes (Eisenhardt and Sull, 2001) and this learning lasts longer (Madsen and Desai, 2010).

Intentional heuristics are cultivated by experience (Chow, 2015). Bauer et al. (2013) find an interesting correlation between the years of experience of managers and their inclination to create and use heuristics. They explain that, based on the less-is-more effect (Gigerenzer, 2008), experienced managers learn the right information to be ignored. Another example of expert auditors that are not influenced by irrelevant information leads to the same conclusion (Shanteau, 1992, as cited in Astebro and Elhedhli, 2006). Both meanings of the word experience are conditions for the generation of heuristics: direct experience of the negative outcome (experiencing) and experience as prolonged exposure to the field (know-how). The relationship between generating heuristics and learning from experience works in both ways. Not only experience is a prerequisite for generating heuristics, but also codifying experiential learning into heuristics is crucial for the effectiveness of trial-and-error learning (Ott et al., 2017).

The process of heuristic generation requires internal attribution. "External attributions may be detrimental for learning heuristics. (...) By contrast, when managers attribute negative outcomes to internal factors (e.g. poor strategy or poor implementation of strategy), they appear much more likely to change behavior since they acknowledge responsibility" (Bingham and Haleblian, 2012, p. 154).

Insights from literature support one of two views: that heuristics are generated at the individual level of the manager or collectively, as a result of group discussions. These two positions are explored below in separate paragraphs and a unifying view is proposed in a third one.

Insights from the sensemaking literature are valuable in this debate, as managers need to make sense of the negative situation, and sensemaking is critical to learning from error (Mailtlis and Christianson, 2017). In this sense, Weick's view (1995) supports the individual origin by claiming that sensemaking begins with a sensemaker. Also, Crossan et al. (1999) maintain that, in organizational learning, insight occurs to individuals, not organizations, and propose a model of organizational learning that starts with the individual phase Intuiting. The origin of proverbs, documented by Mieder (2014, p. 28), can also help to infer, by analogy, that heuristics originate from individuals: "every proverb begins with an individual whose keen insight is accepted and carried forth as a piece of proverbial wisdom." Empirically, Guercini et al. (2015) show that managerial heuristics are initially personal. 
$\mathrm{MD}$

59,7

1630

However, the core of the simple-rules stream of research (Bingham and Eisenhardt, 2011; Bingham and Haleblian, 2012; Bingham et al., 2007, 2019; Sull and Eisenhardt, 2012) documents mainly instances of collective generation by discussions among members of the executive team (Bingham et al., 2019) or through lessons-learned debriefings (Bingham and Haleblian, 2012). This stream of research does not claim the exclusivity of collective generation, maintaining that "organizational learning can also occur through cocreation of knowledge" (Bingham and Haleblian, 2012, p. 171) and that "heuristics move from individuallevel rules of thumb (. . .) to firm-level understandings" (Bingham et al., 2019, p. 121).

Despite the apparent conflict between these two views, this paper proposes a unifying perspective according to which heuristics can be generated both by individuals and collectively, but when a heuristic is born in a group discussion, the first insight still originates from one individual. An illustration of this proposed view is the documented generation, during an Everest climbing expedition (Suarez and Montes, 2019), of the heuristic-turnedpolicy If you see a damaged rope, you have to fix it right away, no matter what. One of the members of the expedition, seeing that the ropes were damaged, had the insight to stop and repair them as they descended, to prevent further damage due to wind and sharp rocks. Back into the tent, the team discussed this insight, accepted the heuristic as a better way for maintaining ropes, and agreed to institutionalize it as a compulsory rule (policy). The advantage of collective generation is that, out of necessity, the heuristic gets articulated faster. Also, when heuristics are generated in group discussions, they result in greater dissemination and increased accuracy (Bingham et al., 2019). When a collective generation of heuristics occurs in multi-hierarchical (Bingham et al., 2019) or cross-functional teams (Sull and Eisenhardt, 2012), the process is more effective, pinpointing the mixed composition of the originating groups as an advantage.

The insights on the generation phase can be summarized in the following proposition:

Proposition 1. Intentional heuristics originate from experienced individual managers, sometimes during group discussions, as they assume responsibility and make sense of negative situations.

\subsection{Articulation}

Weick et al. (2005, p. 413) defines articulation as the process "by which tacit knowledge is made more explicit or usable." Knowledge management scholars include articulation as a key element when they define the domain as "the dynamic process of turning an unreflective practice into a reflective one (...) by helping give a particular shape to collective understandings" (Tsoukas and Vladimirou, 2001, as cited in Hazlett et al., 2005, p. 32). We owe the first use of the term articulated heuristics to Bingham et al. (2007, p. 28): "experience must be articulated into "opportunity capture" heuristics to achieve high-performance." But not any articulation will do. "A precise formulation (. . .) facilitates the sharing of such a decision rule across different business units and generations of managers” (Artinger et al., 2015, p. 44).

The immediate outcome of the generation phase is often a non-articulated heuristic which is enacted tacitly. Evidently, this is not the case for collective generation. The heuristic is first acted upon almost instinctually, without being articulated. Guercini et al. (2015, p. 32) observe that "how the rules are learned is so gradual and natural that only few were able to recall a rule that was newly acquired." Stewart and Patterson (2016, p. 3) study simple rules in teaching and learning and document that "these emergent rules are often implicit or unspoken; teachers and students may follow the expected patterns without even realizing that these influences are at work."

The experienced manager first makes sense of how to prevent the negative outcome by creating a decision rule with (usually) one key criterion. The first attempts to verbalize the heuristic lead, therefore, to a restrictive inequality with a numerical threshold regarding that 
criterion (Berg, 2014, p. 1701). This initial restrictive form (we should not, as opposed to the prescriptive form we should) can be later polished into a prescriptive rule, but inequality and threshold can still be found in a lot of mature managerial heuristics, from Jeff Bezos' famous two-pizza rule: Every internal team should be small enough that it can be fed with two pizzas, to Dell's rule for reorganization: A business must be split in two when its revenue hits $\$ 1$ billion (Eisenhardt and Sull, 2001), and to location choice: For a restaurant location, if rent is more than 4 days revenue, stay out (Atanasiu, 2017).

Heuristics subsequently go through a process of proverbialization. Proverbs are characterized by mnemonic robustness (Shapin, 2001) - they are articulated as to be easily remembered and passed forward. Mieder (2014) pinpoints proverbial markers like parallelism, rhyme or alliteration as means to this robustness. The use of numbers is also an efficient tool for mnemonic robustness. Heuristics literature provides the same insight: "Shared heuristics may take the form of short catchphrases, (. . .) expressed in common language, thoughtprovoking, and preferably with a humorous twist" (Eriksson and Kadefors, 2017, p 501). Proverbiality is important for heuristics' role in coordination: "Simple rules also improve performance because they are easy to remember, (...), easy to communicate, which makes them easier to spread. This facilitates better coordination, even in dispersed organizations" (Bingham and Eisenhardt, 2014, p. 1700). Katsikopoulos $(2010,2016)$ includes this trait into the very definition of heuristics, as "models for making decisions (...) that are easy to understand, apply, and explain.” Table 4 presents examples of managerial heuristics and their proverbial markers to illustrate the proverb-like structure of heuristics.

Not all articulated heuristics have this proverb-like formulation: Intel's rule that Allocation is based on a product's gross margin (Eisenhardt and Sull, 2001) does not rhyme and does not have any humorous twists but is clear and can be easily remembered and communicated. The articulation of heuristics as managerial proverbs facilitates all their important functions as tools for managing knowledge (Maqsood et al., 2004): to capture the tacit knowledge of experienced people in the organization, to make it explicit in a form that is easily remembered by the individual manager herself in order to continuously apply it in her activity, and to make it easy to be shared throughout the organization in formal or informal communication, on account of its proverbial markers.

Articulated heuristics then go through a constant refining process which renders them more precise and strategic, with a higher degree of abstraction and generality. Bingham and Eisenhardt (2011) describe this refining process by studying heuristics generated during the

\begin{tabular}{lll}
\hline Heuristic & Proverbial marker & Source \\
\hline Sell in May and go away & rhyme & Bouman and \\
& & Jacobsen (2002) \\
Sell aspirins rather than vitamins & rhyme, symmetry & Shapin (2001) \\
It takes money to make money & alliteration, rhyme & Shapin (2001) \\
Companies to be acquired must have no more than 75 & repetition, use of & Eisenhardt and Sull \\
employees, 75\% of whom are engineers & numbers & (2001) \\
A bad deal is better than a good lawsuit & surprising contrast & Atanasiu (2017) \\
Buy on the rumour, sell on the fact & symmetry, parallelism & Shapin (2001) \\
If there are 3 "ifs", do not do it! & shortness, use of & Atanasiu (2017) \\
& numbers & Bingham et al. (2007) \\
Enter one country every two months & shortness, use of & numbers \\
If you pay peanuts, you get monkeys & humorous twist & Shapin (2001) \\
Every internal team should be small enough that it can be & humorous twist, use of & Hern (2018) \\
fed with two pizzas & numbers &
\end{tabular}$$
\text { Eisenhardt (2011) describe this refining process by studying heuristics generated during the }
$$

Lifecycle of heuristics as managerial proverbs

1631

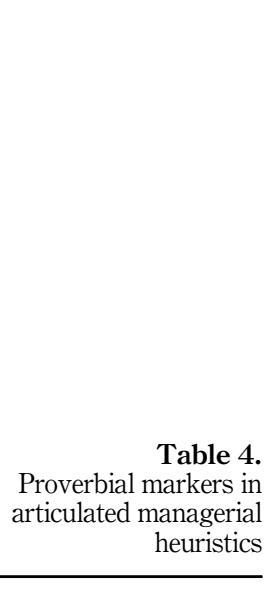


internationalization processes of six technology-based ventures and they provide compelling examples: a heuristic is made more strategic by replacing its naïve criterion (geography Scandinavian countries) with a more actionable one (market size); a heuristic can be finetuned to get a higher degree of precision, by adding another filter to the choice; a heuristic also adapts to a larger variety of contexts by acquiring a higher degree of generality and abstraction (the replacement of a generic target market - governments, insurance companies, banks, with a more generally described customer profile: Sell to organizations with extensive proprietary data and ability to pay, allowing the firm to consider oil companies, insurance firms and manufacturing firms).

There is another benefit of the articulation process: it transforms heuristics from instinctual strategies to deliberately used tools that can be rationally analyzed and employed. As a consequence, Guercini et al. (2014) propose a purposeful process of articulation as a cross-checking mechanism. This builds upon the default-interventionist hypothesis proposed by Basel and Brühl (2013) and puts forward articulation as the key process in transition from System 1 to System 2. Stewart and Patterson (2016, p. 3) show that "simple rules may become evident only after retrospective analysis and reflection" and "deliberate and explicit dialogue about these emergent simple rules is useful to the extent that teachers and students become increasingly aware of whether and how system patterns support shared learning goals."

As for the outcome of this phase, Merlo et al. (2008, p. 199) offer a good synthesis: "An effective heuristic is also one that has been empirically tested and refined over time, is easily communicated and understood, and provides clear guidelines about its implementation (i.e. it is relatively 'simple')."

The process of articulation, as based on these insights, can be summarized in the following proposition:

Proposition 2. Managers articulate their heuristics in a precise, proverb-like formulation, to make them easy to remember and to communicate, then constantly refine and adapt their heuristics to the environment.

\subsection{Sharing}

Not all managerial heuristics get shared. Guercini et al. (2015, p. 26) found that, among salespersons, "heuristics are personal and seldom shared with others"; but, then again, salespersons are known to be rather individualistic. Often, however, like in the case of proverbs, "if the statement contains an element of truth or wisdom, and if it exhibits one or more proverbial markers (. . ), it might catch on and be used first in a small family circle, and subsequently in a village, a city, a region, a country, a continent, and eventually the world." (Schapira, 2000, as cited in Mieder, 2014, p. 31). Mutatis mutandis, this applies to colleagues, team, organization, industry. The literature describes two different ways of diffusion: a natural, social way, through informal communication, and a formal, institutionalized way, through lessons-learned meetings.

Guercini et al. (2015) found that sharing "is mostly in the form of an informal exchange of opinions among close friendly colleagues." Barberà-Mariné et al. (2019, p. 2901) study triage heuristics followed by nurses and show that, in particular, training "acts as a medium to share informal rules among individuals." Bingham et al. (2019) document an informal process, as "knowledge sharing happened daily through informal conversations between managers" (p. 139), but emphasize the role of "extensive communication within and across multiple hierarchical levels" (p. 121). It should also be noted that collectively generated heuristics are born shared. Finally, in addition to sharing heuristics with a colleague, a group or an organization, Kazakova and Geiger (2015) and Monaghan and Tippmann (2018) document industry-level heuristics. Informal sharing occurs in a natural way, until "each (heuristic) is shared broadly by many individuals in each group” (Oliver and Roos, 2005, p. 898). 
The informal process results in a diffuse, undocumented, but efficient heuristics portfolio of a firm. The perfect illustration is given by a respondent in Bingham and Eisenhardt's (2011) study: "It's not really coded anywhere. It's been diffused in the company, so it gets into everybody's head" (Bingham and Eisenhardt, 2011, p. 1450).

Formal sharing occurs in "regular meetings with fixed timelines (...) that help general heuristics (...) to emerge" as lessons learned from negative outcomes (Bingham and Haleblian, 2012, p. 171). However, McClory et al. (2017, p. 1322) found that "few organizations identify and capture relevant lessons, and fewer utilize them." The sharing of heuristics from individual to organizational level, whether formal or informal, is subject to the danger of hasty generalization. Artinger et al. (2015, p. 39) warn that "some heuristics can apply at both levels if the central environmental features that determine the ecological rationality are shared" and that "the transfer between these two levels is not always a trivial task and requires identifying the functional principles and boundary conditions."

The two paths of sharing, as described by these studies, can be summarized into a third proposition:

Proposition 3. Heuristics are shared either in an informal way, through socialization, resulting in a diffuse, but efficient heuristics portfolio of a firm, or in a formal way, through regular lessons-learned meetings, resulting in a documented set of simple rules.

\subsection{Application}

The dual sharing process can be paralleled with a dual process for adoption and application, with soft adoption turning shared heuristics into optional guidelines and hard adoption turning them into policies.

Soft adoption occurs through informal communication and heuristics are adopted under the expert authority of the manager who shares them. As an example, during training, "experienced nurses can show beginners how to apply triage protocols for priority levels' assignment” (Barberà-Mariné et al., 2019, p. 2901). The application of a soft adopted heuristic is optional and the adopter is more likely to question, adapt, refine, change or abandon the heuristic. Soft adoption under expert authority institutionalizes heuristics into optional guidelines.

Hard adoption of a heuristic as policy can be the consequence of hierarchical authority or of collective authority. In the case of Jeff Bezos' two-pizza rule, his insight is shared and transformed into policy almost from inception, based on the hierarchical authority of the CEO. The hierarchical adoption of a heuristic can make it sticky, less adaptable to the environment. This danger is signaled by Artinger et al. (2015, p. 36): "not only the question of how heuristic strategies are initially selected but particularly how they are switched after they have become maladapted largely remains a central but not yet sufficiently answered question.” Another type of hard adoption is through the consensus mechanism described by Bingham and Haleblian (2012), when negative outcomes are jointly analyzed by multiple levels of management and common solutions are expressed as strategical heuristics, under collective authority. Hard adoption under collective authority allows for constant refinement of shared heuristics, even after they become policy (Bingham and Eisenhardt, 2011).

The two paths of adoption that lead to institutionalized heuristics can be summarized in this last proposition:

Proposition 4. Shared heuristics can be institutionalized through soft adoption into optional guidelines, under expert authority, or through hard adoption into policies, under hierarchical or collective authority. 
$\mathrm{MD}$

59,7

1634

\section{Discussion and conclusion}

This paper contributes to the heuristic literature by using a theory-based approach to open the black box of how heuristics emerge and how various factors (experience, attribution, proverbialization, socialization, authority, etc.) shape this process. It starts by laying the theoretical foundation of the study: using extant literature, it synthesizes a definition for managerial heuristics as cognitive shortcuts for making decisions that use fewer resources than analytical algorithms in order to reach good enough solutions for difficult managerial problems. It then clarifies, also based on a synthetic analysis, the existence of two categories of heuristics: intentional heuristics that are idiosyncratic, learned from experience, and employed purposefully, and unintentional heuristics that are systemic, inherent or innate, and are used non-deliberately, and maps these two categories on the main three streams of research: heuristics-and-biases, fast-and-frugal, and simple-rules.

In the main analysis of this paper, the outline of a process model of heuristic emergence is built by putting together the four stages of intentional heuristics resulted from a systematic literature review - non-articulated, articulated, shared, and institutionalized, and the four processes depicted in an adapted dynamic framework (Mertins et al., 2003) generation, articulation, sharing, and application, as presented in Figure 1. Further, this process model of heuristic emergence is detailed by putting together insights from neighboring literatures and from paremiology (the science of proverbs) for describing the four phases of the process, which are summarized in four propositions. By putting these four propositions together, this paper provides here a short description of the lifecycle of a managerial heuristic:

\footnotetext{
Intentional heuristics originate from experienced individual managers, sometimes during group discussions, as they assume responsibility and make sense of negative situations. Managers articulate their heuristics in a precise, proverb-like formulation, to make them easy to remember and to communicate, then constantly refine and adapt their heuristics to the environment. Heuristics are shared either in an informal way, through socialization, resulting in a diffuse, but efficient heuristics portfolio of a firm, or in a formal way, through regular lessons-learned meetings, resulting in a documented set of simple rules. Shared heuristics can be institutionalized through soft adoption into optional guidelines, under expert authority, or through hard adoption into policies, under hierarchical or collective authority.
}

The paper discusses the role of negative situations as triggers for a sensemaking process that generates insight and the role of experience, experiencing and internal attribution to turn this insight into an unspoken rule. According to principles from the organizational learning and sensemaking literatures and to some empirical studies, the generation of heuristics happens at individual level. However, several other studies document a collective generation of heuristics. Based on an illustrative case, this paper proposes a view that reconciles the two perspectives. According to this view, heuristics can be generated in groups, but still based on insights from one individual. In a blended-theory approach, this paper further identifies heuristics and proverbs as belonging to the same family and draws insights from paremiology to propose that heuristics go through a process of proverbialization that renders them easy to remember and communicate. Two paths of sharing heuristics to colleagues, teams, organizations, and industry are identified in extant literature, and then described and analyzed: formal and informal sharing. Finally, this paper proposes that heuristics are institutionalized as a result of three types of authority, and that each type of authority leads to one of two possible applications: optional, as guidelines, and compulsory, as policy. Expert authority leads to soft adoption of heuristics as guidelines, prone to questioning, adapting, and abandoning. Collective authority, when a lesson is learned and the group adopts it as a managerial proverb, leads to hard adoption, with the group in charge for future developments. When the boss directly turns their heuristic into policy, hierarchical 
authority leads to a different kind of hard adoption, one that may lead to the heuristic being sticky, impossible to adapt to future situations.

A second contribution is bridging different literatures into a unified view on how managers and firms make sense of their experience in order to learn managerial proverbs that store and disseminate knowledge across levels. Insights and principles from sensemaking, organizational learning, knowledge management and paremiology fit well together into this view, proposing, in turn, managerial heuristics as a valid research topic in their respective domains.

The main path for future research proposed by this paper is to consider the four propositions in an empirical setting. Another path is proposed to scholars in neighboring domains: to consider managerial heuristics as valuable research objects for their studies and as complex concepts for their theory building.

The findings of this paper are mainly based on a literature that is still fairly young, therefore some of the schematic transcriptions of reality may be adjusted following further research and interpretations. In some cases, this study describes certain phases based on just a few empirical studies, leading perhaps to a limited view of the process. Furthermore, as this paper proposes a process model, it has the inherent approximating limitation of any model. Methodologically, this process model is based on reviewing the literature and on building a dynamic perspective by putting together static observations; this approach is certainly painting an imprecise approximation of the real process. Another limitation of this model is the lack of a time dimension that should be present in any description of a process.

For practitioners, this paper provides a theoretical ground for influential works like "Principles. Life and Work" by Ray Dalio and, by describing a process model of heuristic emergence, allows practitioners to catalyze their own process of generating these useful decision-making tools (Gigerenzer, 2008). Most authors recommend managers to actively develop a heuristic portfolio: "Given its importance, the heuristics portfolio of a company is an intangible asset that should be maintained, cultivated, and refined continuously in a bottom up logic" (Guercini et al., 2015, p. 35). Extrapolating from the two ways of sharing described in this paper and based on the reviewed literature, a recommendation can therefore be made to managers to actively generate and share heuristics. Managers could organize regular lessonslearned meetings that purposefully store these lessons into proverb-like heuristics that are easy to remember, to apply, and to communicate. Informal sharing can be catalyzed by actively encouraging experienced managers to socialize and share their managerial proverbs with their younger colleagues. Another recommendation, for CEOs this time, is to empower the organization to question, adapt, transform, and even abandon policies which resulted from their personal heuristics.

The constant building and refining of a manager's or a firm's portfolio of heuristics is important because this portfolio represents experience materialized into strategic capabilities. This paper reviews relevant literature and synthesizes a process model of how managers and firms generate, articulate, share, and apply their heuristics, offering a coherent, step-by-step dynamic perspective of these largely unexplored activities and a better understanding of how managerial proverbs store knowledge gained through experience.

\section{References}

Ambos, T.C., Cesinger, B., Eggers, F. and Kraus, S. (2020), "How does de-globalization affect location decisions? A study of managerial perceptions of risk and return", Global Strategy Journal, Vol. 10 No. 1, pp. 210-236.
Lifecycle of heuristics as managerial proverbs

1635 
Artinger, F., Petersen, M., Gigerenzer, G. and Weibler, J. (2015), "Heuristics as adaptive decision strategies in management", Journal of Organizational Behavior, Vol. 36 S1, pp. 33-52.

Astebro, T. and Elhedhli, S. (2006), "The effectiveness of simple decision heuristics: forecasting commercial success for early-stage ventures”, Management Science, Vol. 52 No. 3, pp. 395-409.

Atanasiu, R. (2017), "The use of heuristics in business decisions", Proceedings of the 11th International Management Conference, 2017, Bucharest, pp. 1046-1053.

Atanasiu, R. and Ruotsalainen, R. (2019), "The role of managerial heuristics in organizational decisionmaking and beyond", Academy of Management Proceedings, 2019.

Baker, T.K. and Collier, D.A. (1999), "A comparative revenue analysis of hotel yield management heuristics”, Decision Sciences, Vol. 30 No. 1, pp. 239-263.

Barberà-Mariné, M.G., Cannavacciuolo, L., Ippolito, A., Ponsiglione, C. and Zollo, G. (2019), "The weight of organizational factors on heuristics", Management Decision, Vol. 57 No. 11, pp. 2890-2910.

Basel, J.S. and Brühl, R. (2013), "Rationality and dual process models of reasoning in managerial cognition and decision-making”, European Management Journal, Vol. 31 No. 6, pp. 745-754.

Bateman, H., et al. (2017), "Default and naive diversification heuristics in annuity choice", Australian Journal of Management, Vol. 42 No. 1, p. 32.

Bauer, J.C., Schmitt, P., Morwitz, V.G. and Winer, R.S. (2013), "Managerial decision making in customer management: adaptive, fast and frugal?", Journal of the Academy of Marketing Science: Official Publication of the Academy of Marketing Science, Vol. 41 No. 4, pp. 436-455.

Berg, N. (2014), "Success from satisficing and imitation: entrepreneurs' location choice and implications of heuristics for local economic development", Journal of Business Research, Vol. 67 No. 8, pp. 1700-1709.

Bingham, C.B. and Eisenhardt, K.M. (2011), "Rational heuristics: the 'simple rules' that strategists learn from process experience”, Strategic Management Journal, Vol. 32 No. 13, pp. 1437-1464.

Bingham, C.B. and Eisenhardt, K.M. (2014), "Response to Vuori and Vuori's commentary on 'Heuristics in the strategy context", Strategic Management Journal, Vol. 35 No. 11, pp. 1698-1702.

Bingham, C.B. and Haleblian, J. (2012), "How firms learn heuristics: uncovering missing components of organizational learning", Strategic Entrepreneurship Journal, Vol. 6, pp. 152-177.

Bingham, C.B., Eisenhardt, K.M. and Furr, N.R. (2007), "What makes a process a capability? Heuristics, strategy, and effective capture of opportunities", Strategic Entrepreneurship Journal, Vol. 1 Nos 1/2, pp. 27-47.

Bingham, C.B., Howell, T. and Ott, T.E. (2019), "Capability creation: heuristics as microfoundations”, Strategic Entrepreneurship Journal, Vol. 13 No. 2, pp. 121-153.

Bouman, S. and Jacobsen, B. (2002), "The Halloween indicator, 'sell in may and go away': another puzzle", American Economic Review, Vol. 92 No. 5, pp. 1618-1635.

Bryant, P. (2007), "Self-Regulation and decision heuristics in entrepreneurial opportunity evaluation and exploitation", Management Decision, Vol. 45 No. 4, pp. 732-748.

Burlinson, A., Giulietti, M. and Battisti, G. (2018), "Technology adoption, consumer inattention and heuristic decision-making: evidence from a UK district heating scheme”, Research Policy, Vol. 47 No. 10, pp. 1873-1886.

Chen, C.-S., Cheng, J.-C., Lin, F.-C. and Peng, C. (2017), "The role of house money effect and availability heuristic in investor behavior", Management Decision, Vol. 55 No. 8, pp. 1598-1612.

Chow, S.J. (2015), "Many meanings of "heuristic", The British Journal for the Philosophy of Science, Vol. 66 No. 4, pp. 977-1016. 
Cropanzano, R. (2009), "Writing nonempirical articles for journal of management: general thoughts and suggestions", Journal of Management, Vol. 35 No. 6, pp. 1304-1311.

Crossan, M.M., Lane, H.W. and White, R.E. (1999), "An organizational learning framework: from intuition to institution", Academy of Management Review, Vol. 24, pp. 522-537.

Dane, E. and Pratt, M.G. (2007), "Exploring intuition and its role in managerial decision making", Academy of Management Review, Vol. 32, pp. 33-54.

DeMiguel, V., Garlappi, L. and Uppal, R. (2009), "Optimal versus naive diversification: how inefficient is the 1/n portfolio strategy?", The Review of Financial Studies, Vol. 22 No. 5, pp. 1915-1953.

Devers, C.E., Wiseman, R.M. and Holmes, R.M. (2007), "The effects of endowment and loss aversion in managerial stock option valuation", Academy of Management Journal, Vol. 50 No. 1, pp. 191-208.

Eberhart (née Moser), A.K. and Naderer, G. (2017), "Quantitative and qualitative insights into consumers' sustainable purchasing behaviour: a segmentation approach based on motives and heuristic cues", Journal of Marketing Management, Vol. 33 Nos 13/14, pp. 1149-1169.

Eisenhardt, K.M. and Bingham, C.B. (2017), "Superior strategy in entrepreneurial settings: thinking, doing, and the logic of opportunity", Strategy Science, Vol. 2 No. 4, pp. 246-257.

Eisenhardt, K.M. and Sull, D.N. (2001), "Strategy as simple rules", Harvard Business Review, Vol. 79 No. 1, pp. 100-116.

Eriksson, T. and Kadefors, A. (2017), "Organisational design and development in a large rail tunnel project - influence of heuristics and mantras", International Journal of Project Management, Vol. 35 No. 3, pp. 492-503.

Forbes, W., Hudson, R., Skerratt, L. and Soufian, M. (2015), "Which heuristics can aid financialdecision-making?”, International Review of Financial Analysis, Vol. 42, pp. 199-210.

Gigerenzer, G. (1996), "On narrow norms and vague heuristics: a reply to Kahneman and Tversky (1996)”, Psychological Review, Vol. 103 No. 3, p. 592.

Gigerenzer, G. (2008), "Why heuristics work", Perspectives on Psychological Science, Vol. 3 No. 1, pp. 20-29.

Gigerenzer, G. (2016), "Towards a rational theory of heuristics", in Frantz, R. and Marsh, L. (Eds), Minds, Models and Milieux. Archival Insights into the Evolution of Economics, Palgrave Macmillan, London.

Gigerenzer, G. and Brighton, H. (2009), "Homo heuristicus: why biased minds make better inferences", Topics in Cognitive Science, Vol. 1 No. 1, pp. 107-143.

Gigerenzer, G. and Gaissmaier, W. (2011), "Heuristic decision making", Annual Review of Psychology, Vol. 62, pp. 451-482.

Gigerenzer, G. and Goldstein, D.G. (1996), "Reasoning the fast and frugal way: models of bounded rationality", Psychological Review, Vol. 103 No. 4, pp. 650-669.

Gigerenzer, G. and Todd, P.M. and the ABC Research Group (1999), Simple Heuristics that Make Us Smart, Oxford University Press, Oxford.

Gilson, L.L. and Goldberg, C.B. (2015), "Editors' comment: so, what is a conceptual paper?”, Group and Organization Management, Vol. 40 No. 2, pp. 127-130.

Graffin, S.D., Boivie, S. and Carpenter, M.A. (2013), "Examining CEO succession and the role of heuristics in early-stage CEO evaluation”, Strategic Management Journal, Vol. 34 No. 4, p. 383.

Guercini, S. (2012), "New approaches to heuristic processes and entrepreneurial cognition of the market", Journal of Research in Marketing and Entrepreneurship, Vol. 14 No. 2, pp. 199-213.

Guercini, S., La Rocca, A., Runfola, A. and Snehota, I. (2014), "Interaction behaviors in business relationships and heuristics: issues for management and research agenda", Industrial Marketing Management, Vol. 43 No. 6, pp. 929-937.
Lifecycle of heuristics as managerial proverbs 
Guercini, S., La Rocca, A., Runfola, A. and Snehota, I. (2015), "Heuristics in customer-supplier interaction”, Industrial Marketing Management, Vol. 48, pp. 26-37.

Hafenbrädl, S., Waeger, D., Marewski, J.N. and Gigerenzer, G. (2016), "Applied decision making with fast-and-frugal heuristics", Journal of Applied Research in Memory and Cognition, Vol. 5 No. 2 , pp. 215-231.

Hauser, J.R. (2014), “Consideration-set heuristics”, Journal of Business Research, Vol. 67 No. 8, p. 1688.

Hazlett, S.-A., McAdam, R. and Gallagher, S. (2005), "Theory building in knowledge management: in search of paradigms", Journal of Management Inquiry, Vol. 14 No. 1, pp. 31-42.

Hern, A. (2018), "The two-pizza rule and the secret of Amazon's success", The Guardian, April 24, available at: https://www.theguardian.com/technology/2018/apr/24/the-two-pizza-rule-and-thesecret-of-amazons-success.

Hutchinson, J.W., Alba, J.W. and Eisenstein, E.M. (2010), "Heuristics and biases in data-based decision making: effects of experience, training, and graphical data displays", Journal of Marketing Research, Vol. 47 No. 4, pp. 627-642.

Jaakkola, E. (2020), "Designing conceptual articles: four approaches", Academy of Marketing Science Review, Vol. 10 Nos 1/2, pp. 18-26.

Jayakumar, T. (2016), "Behavioral lessons from Flipkart's big-billion day sale", Competitiveness Review, Vol. 26 No. 4, pp. 453-475.

Johnson, J. and Tellis, G.J. (2005), "Blowing bubbles: heuristics and biases in the run-up of stock prices", Journal of the Academy of Marketing Science, Vol. 33 No. 4, pp. 486-503.

Kahneman, D. (2012), Thinking, Fast and Slow, Penguin, London.

Kahneman, D. and Tversky, A. (1996), "On the reality of cognitive illusions”, Psychological Review, Vol. 103 No. 3, pp. 582-591.

Katsikopoulos, K.V. (2010), "Psychological heuristics for making inferences: definition, performance, and the emerging theory and practice", Decision Analysis, Vol. 8 No. 1, pp. 10-29.

Katsikopoulos, K.V. (2016), "Behavior with models: the role of psychological heuristics in operational research", in Kunc, M., Malpass, J. and White, L. (Eds), Behavioral Operational Research, Palgrave Macmillan, London.

Kazakova, T.V. (2015), "How organizational heuristics emerge in strategy making", Academy of Management Proceedings, Vol. 2015 No. 1, p. 17327.

Kazakova, T.V. and Geiger, D. (2015), "The complexity of simple rules: heuristics in strategic decision making”, Academy of Management Proceedings, Vol. 2015 No. 1, p. 17732.

Loock, M. and Hinnen, J. (2015), "Heuristics in organizations: a review and a research agenda", Journal of Business Research, Vol. 68 No. 9, pp. 2027-2036.

Luan, S., Reb, J. and Gigerenzer, G. (2019), "Ecological rationality: fast-and-frugal heuristics for managerial decision making under uncertainty", Academy of Management Journal, Vol. 62 No. 6, p. 1735.

Macchi, L. (2000), "Partitive formulation of information in probabilistic problems: beyond heuristics and frequency format explanations", Organizational Behavior and Human Decision Processes, Vol. 82 No. 2, pp. 217-236.

Madsen, P.M. and Desai, V. (2010), "Failing to learn? The effects of failure and success on organizational learning in the global orbital launch vehicle industry", Academy of Management Journal, Vol. 53 No. 3, pp. 451-476.

Maitland, E. and Sammartino, A. (2015), "Decision making and uncertainty: the role of heuristics and experience in assessing a politically hazardous environment", Strategic Management Journal, Vol. 36 No. 10, p. 1554.

Maitlis, S. and Christianson, M. (2014), "Sensemaking in organizations: taking stock and moving forward”, Academy of Management Annals, Vol. 8 No. 1, pp. 57-125. 
Manimala, M.J. (1992), "Entrepreneurial heuristics: a comparison between high PI (pioneeringinnovative) and low PI ventures", Journal of Business Venturing, Vol. 7, pp. 477-504.

Maqsood, T., Finegan, A. and L. Armstrong, H. (2004), "Biases and heuristics in judgment and decision making: the dark side of tacit knowledge", Issues in Informing Science and Information Technology, Vol. 1, pp. 0295-0301.

Martin, G.P., Wiseman, R.M. and Gomez-Mejia, L.R. (2016), "Going short-term or long-term? Ceo stock options and temporal orientation in the presence of slack", Strategic Management Journal, Vol. 37 No. 12, pp. 2463-2480.

McClory, S., Read, M. and Labib, A. (2017), "Conceptualising the lessons-learned process in project management: towards a triple-loop learning framework", International Journal of Project Management, Vol. 35 No. 7, pp. 1322-1335.

Merlo, O., Lukas, B.A. and Whitwell, G.J. (2008), "Heuristics revisited: implications for marketing research and practice", Marketing Theory, Vol. 8 No. 2, pp. 189-204.

Mertins, K., Heisig, P. and Vorbeck, J. (2003), Knowledge Management-Concepts and Best Practices, Springer Verlag Berlin Heidelberg, New York, NY.

Meszaros, J.R. (1999), "Preventive choices: organizations' heuristics, decision processes and catastrophic risks", Journal of Management Studies, Vol. 36 No. 7, pp. 977-998.

Mieder, W. (2014), "Origin of proverbs", in Hrisztova-Gotthardt, H. and Aleksa Varga, M. (Eds), Introduction to Paremiology: A Comprehensive Guide to Proverb Studies, Chapter 2, pp. 28-48, Sciendo De Gruyter.

Miller, K.D. and Shapira, Z. (2004), "An empirical test of heuristics and biases affecting real option valuation”, Strategic Management Journal, Vol. 25 No. 3, pp. 269-284.

Monaghan, S. and Tippmann, E. (2018), "Becoming a multinational enterprise: using industry recipes to achieve rapid multinationalization”, Journal of International Business Studies, Vol. 49 No. 4, pp. 473-495.

Mousavi, S. and Gigerenzer, G. (2014), "Risk, uncertainty, and heuristics", Journal of Business Research, Vol. 67 No. 8, pp. 1671-1678.

Mousavi, S., Gigerenzer, G. and Kheirandish, R. (2017), "Rethinking behavioral economics through fast-and-frugal heuristics", in Frantz, R., Chen, S., Dopfer, K. and Mousavi, S. (Eds), Handbook of Behavioral Economics, Routledge, pp. 280-296.

Newell, B.R., Weston, N.J. and Shanks, D.R. (2003), "Empirical tests of a fast-and-frugal heuristic: not everyone "takes-the-best”, Organizational Behavior and Human Decision Processes, Vol. 91 No. 1, pp. 82-96.

Nonaka, I. (1994), “A dynamic theory of organizational knowledge creation”, Organization Science, Vol. 5 No. 1, pp. 14-37.

Okhuysen, G. and Bonardi, J.P. (2011), "The challenges of building theory by combining lenses", Academy of Management Review, Vol. 36, pp. 6-11.

Oliver, D. and Roos, J. (2005), "Decision-making in high-velocity environments: the importance of guiding principles", Organization Studies, Vol. 26 No. 6, pp. 889-913.

Ott, T.E., Eisenhardt, K.M. and Bingham, C.B. (2017), "Strategy formation in entrepreneurial settings: past insights and future directions", Strategic Entrepreneurship Journal, Vol. 11 No. 3, pp. 306-325.

Palmatier, R.W., Houston, M.B. and Hulland, J. (2017), "Review articles: purpose, process, and structure”, Journal of the Academy of Marketing Science, Vol. 1 No. 46, pp. 1-5.

Persson, A. and Ryals, L. (2014), "Making customer relationship decisions: analytics vs rules of thumb", Journal of Business Research, Vol. 67 No. 8, pp. 1725-1732.

Pham, M.T. and Avnet, T. (2009), "Contingent reliance on the affect heuristic as a function of regulatory focus", Organizational Behavior and Human Decision Processes, Vol. 108 No. 2, p. 267.
Lifecycle of heuristics as managerial proverbs

1639 
Phillips, D.C. (2017), "Stopping on nine: evidence of heuristic managerial decision-making in major league baseball pitcher substitutions", Southern Economic Journal, Vol. 84 No. 2, pp. 577-599.

Ranjbarfard, M., Aghdasi, M., López-Sáez, P. and López, J.E.N. (2014), "The barriers of knowledge generation, storage, distribution and application that impede learning in gas and petroleum companies", Journal of Knowledge Management, Vol. 18 No. 3, pp. 494-522.

Roch, S.G., Lane, J.A.S., Samuelson, C.D., Allison, S.T. and Dent, J.L. (2000), "Cognitive load and the equality heuristic: a two-stage model of resource overconsumption in small groups", Organizational Behavior and Human Decision Processes, Vol. 83 No. 2, pp. 185-212.

Rusetsky, A. (2014), "Pricing by intuition: managerial choices with limited information", Journal of Business Research, Vol. 67 No. 8, pp. 1733-1743.

Sayed, S.A. (2016), "Does sophisticated DCF outperform heuristics driven PE? Evidence from India", Journal of Advances in Management Research, Vol. 13 No. 1, pp. $42-58$.

Schiffels, S., Fliedner, T. and Kolisch, R. (2018), "Human behavior in project portfolio selection: insights from an experimental study", Decision Sciences, Vol. 49, pp. 1061-1087.

Shah, A.K. and Oppenheimer, D.M. (2008), "Heuristics made easy: an effort-reduction framework", Psychological Bulletin, Vol. 134 No. 2, p. 207.

Shapin, S. (2001), "Proverbial Economies: how an understanding of some linguistic and social features of common sense can throw light on more prestigious bodies of knowledge, science for example", Social Studies of Science, Vol. 31 No. 5, pp. 731-769.

Stewart, M.A. and Patterson, L. (2016), "Authentic engagement or just 'playing school?: simple rules and complex literacy learning for adolescent English learners", 2016 Dec 31 Edition 1, Emergence: Complexity and Organization, Vol. 18 Nos 3/4, pp. 54-82.

Suarez, F.F. and Montes, J.S. (2019), “An integrative perspective of organizational responses: routines, heuristics, and improvisations in a mount everest expedition”, Organization Science, Vol. 30 No. 3, p. 573.

Sull, D. and Eisenhardt, K.M. (2012), "Simple rules for a complex world", Harvard Business Review, Vol. 90 No. 9.

Tsay, C.-J. (2014), "The vision heuristic: judging music ensembles by sight alone”, Organizational Behavior and Human Decision Processes, Vol. 124 No. 1, p. 24.

Tseng, S.Y. and Yang, C., "The role of information searches in investment choice variation: digital information, advice seeking and heuristics", African Journal of Business Management, Vol. 5 No. 12 , pp. 4934-4944.

Turturea, R. (2018), "Heuristics in the decision-making of crowd investors", Academy of Management Proceedings 2018.

Tversky, A. and Kahneman, D. (1973), "Availability: a heuristic for judging frequency and probability”, Cognitive Psychology, Vol. 5 No. 2, pp. 207-232.

Tversky, A. and Kahneman, D. (1974), “Judgment under uncertainty: heuristics and biases”, Science, Vol. 185 No. 4157, pp. 1124-1131.

Venkatraman, V., Payne, J.W. and Huettel, S.A. (2014), “An overall probability of winning heuristic for complex risky decisions: choice and eye fixation evidence”, Organizational Behavior and Human Decision Processes, Vol. 125 No. 2, p. 73.

Weick, K.E. (1995), "The collapse of sensemaking in organizations: the Mann Gulch disaster", Administrative Science Quarterly, Vol. 38 No. 4, pp. 628-652.

Weick, K.E., Sutcliffe, K.M. and Obstfeld, D. (2005), "Organizing and the process of sensemaking", Organization Science, Vol. 16 No. 4, pp. 409-421.

West, D.C., Christodoulides, G. and Bonhomme, J. (2017), "How do heuristics influence creative decisions at advertising agencies? Factors that affect managerial decision makin when choosing ideas to show the client”, Journal of Advertising Research, Vol. 58 No. 2, pp. 189-201. 
Wickham, P.A. (2003), "The representativeness heuristic in judgements involving entrepreneurial success and failure”, Management Decision, Vol. 41 No. 2, pp. 156-167.

Will, R.P. and Hardaway, D.E. (1994), "Advice for building expert systems: precepts or proverbs?”, Interfaces, Vol. 24 No. 6, pp. 79-81.

Wübben, M. and Wangenheim, F.V. (2008), "Instant customer base analysis: managerial heuristics often 'get it right", Journal of Marketing, Vol. 72 No. 3, pp. 82-93.

\section{Further reading}

Caramelli, M. and Carberry, E.J. (2014), "Understanding employee preferences for investing in employer stock: evidence from France”, Human Resource Management Journal, Vol. 24 No. 4, pp. 548-566.

\section{Corresponding author}

Radu Atanasiu can be contacted at: radu@msmromania.org
Lifecycle of heuristics as managerial proverbs

1641

For instructions on how to order reprints of this article, please visit our website: www.emeraldgrouppublishing.com/licensing/reprints.htm Or contact us for further details: permissions@emeraldinsight.com 